\title{
Influence of the Temperature and Cell Line on the Adsorption and Replication of Five Fish Rotaviruses
}

\author{
C. P. Dopazo ${ }^{1, *}$, B. Lupiani ${ }^{1, \dagger}$, C. Rivas ${ }^{1}$, B. Novoa $^{2}$, J. L. Barja ${ }^{1}$ \\ and A. E. Toranzo ${ }^{1}$ \\ ${ }^{1}$ Department of Microbiology and Parasitology, Faculty of Biologia, \\ University of Santiago, Santiago de Compostela 15706, Spain \\ ${ }^{2}$ Institute of Marine Research, CSIC, Eduardo Cabello 6, \\ Bouzas 36206 Vigo, Spain
}

(Received March 6, 1991)

\begin{abstract}
The infectivity of five fish rotaviruses was assayed on 4 fish and two mammalian cell lines at different temperatures. These viruses were isolated recently from turbot (TRV), smelt (SRV), striped bass (SBR) and Atlantic salmon (ASR and HBR). The two mammalian lines, MA 104 and MDBK, were not susceptible to any of the viruses assayed, although viruses were adsorbed by the cells at certain temperatures. Of the four fish cell lines employed (CHSE-214, FHM, EPC and BB), only FHM cell failed to support the the growth of all the viruses. The EPC cells were susceptible, but the titers were low $\left(\leq 10^{5.5} \mathrm{TCID}_{50} /\right.$ $\mathrm{m} l$ ). Although the BB cells proved to be very useful for the replication of SRV, the Atlantic salmon rotavirus failed to grow in this cell line. The CHSE-214 cell is the optimal cell line for all these rotaviruses because they produced relatively high titers (between $10^{6.25}$ and $10^{9.25} \mathrm{TCID}_{50} / \mathrm{ml}$ ) when the cells were incubated at $15^{\circ} \mathrm{C}$.
\end{abstract}

One of the more recent groups incorporated to the fish virology is the family Reoviridae, being reported the first isolates belonging to this family at the end of the 70's (Meyers, 1979; Plumb et al., 1979), and since then many other researchers have reported the isolation of reolike viruses. Although these viruses share properties with Reoviridae, they show characteristics not exactly coincident with any of the genera included in this family. Therefore, Winton et al. (1987) suggested the name Aquareovirus for a new genus to group these viruses isolated from poikilothermic animals. Recently, new rotaviruses have been reported from various fishes (Baya et al., 1990; Dopazo et al., 1989; Hetrick et al., 1989; Lupiani et al., 1989; Samal et al., 1991).

As is well known, one of the first steps to characterize a new virus is the study of its

* Author to whom correspondence should be addressed.

† Present address: Department of Microbiology, University of Maryland, College Park MD20742, USA. infectivity on different cell lines, as well as its thermostability. Little information, however, is available on these matters of the aquareoviruses (Amend et al., 1984; Hsu et al., 1989; Meyers, 1979; Plumb et al., 1979; Schwedler and Plumb, 1982).

In this paper we compare the adsorption ability and the infectivity of 5 recent rotavirus isolates on 4 fish and 2 mammlian cell lines. In addition, the influence of the temperature on the adsorption and replication of these viruses was also evaluated.

\section{Material and Methods}

\section{Viral Strains}

The five fish rotaviruses used in this study were turbot rotavirus (VTR) isolated in Spain from diseased turbot (Scophthalmus maximus) by Lupiani et al. (1989); smelt rotavirus (SRV), isolated in Canada from smelt (Osmerus mordax) by Moore et al. (1988) and identified by Marshall et al. (1990); striped bass rotavirus (SBR), isolated from diseased striped bass (Morone sax- 
atilis) by Baya et al. (1990) in USA; ASR and HBR, isolated from Atlantic salmon (Salmo salar) by Moore in Canada, and Hetrick and Baya in USA, respectively (unpublished isolations).

\section{Cell Lines and Culture Conditions}

The fish cell lines asssayed were CHSE-214, EPC, FHM and BB. The cells were continuously cultured in Eagle's minimum essential medium (EMEM), supplemented with $10 \%$ foetal calf serum (FBS), penicillin $(100 \mathrm{iu} / \mathrm{ml})$ and streptomycin $(100 \mu \mathrm{g} / \mathrm{ml})$. EPC, BB and FHM cells were incubated at $25^{\circ} \mathrm{C}$, and CHSE-214 cells at $15^{\circ} \mathrm{C}$. Monolayers were maintained at $15^{\circ} \mathrm{C}$ using EMEM with no serum.

Two mammalian lines, MA104 (fetal rhesus monkey) and MDBK (bovine kidney), commonly used for the culture of rotavirus from homeotherms, were also assayed. They were cultured at $37^{\circ} \mathrm{C}$ with EMEM supplemented with $6 \%$ FBS, and for the maintenance EMEM without serum was used.

\section{Viral Adsorption on Cells}

The six cell lines were cultured in $25 \mathrm{~cm}^{2}$ flasks. When the monolayers were confluent, the medium was withdrawn. Then, $1 \mathrm{ml}$ of the corresponding virus was inoculated into the flasks at a multiplicity of infection (M.O.I.) ranging between 0.01 and 0.1 . Flasks of the mammalian cells were incubated at $15,20,25$, 30 and $37^{\circ} \mathrm{C}$. Whereas the adsorption assays on CHSE-214, FHM and CPC cells were conducted at 15,20 and $25^{\circ} \mathrm{C}$, the $\mathrm{BB}$ cells were incubated also at $30^{\circ} \mathrm{C}$. After an adsorption period of $1 \mathrm{~h}$, each inoculum was totally recovered and titrated to determine the quantity of virus that did not adsorb to the cells.

Titrations were carried out in 96 well plates of CHSE-214 cells and the titers were calculated according to Reed and Müench (1938). The results were expressed as percentage of virus adsorbed, with respect to the total virus inoculated.

\section{Cell Susceptibility}

After the adsorption period, $5 \mathrm{~m} l$ of EMEM without serum were added to the inoculated flasks and then incubated at the corresponding temperature. Flasks were observed daily to determine the time to appearance of CPE and the time to total destruction of the monolayer. In the case of FHM and EPC cells, the cell susceptibility to the rotavirus was also tested at $30^{\circ} \mathrm{C}$. Control flasks of each cell line were incubated at the different temperatures. When the monolayers were totally destroyed, the flasks were maintained at $-80^{\circ} \mathrm{C}$ until viral titration. After a maximum incubation period of 45 days, flasks with no CPE were rejected. When CPE was observed but not total destruction occurred, the cells were disrupted by 2 rapid cycles of freezing and thawing, and the cell suspension was frozen at $-80^{\circ} \mathrm{C}$ until titration. Virus titers were calculated according to the Reed \& Müench method using 96 well plates of the respective cell lines.

\section{Temperature Sensitivity Assay}

This assay was conducted to determine the possible viral inactivation occurring during the adsorption period. The five fish viruses were diluted in EMEM to obtain an initial titer of about $10^{5} \mathrm{TCID}_{50} / \mathrm{ml}$. The dilution of each virus was distributed in $4 \mathrm{~m} l$ aliquots, using $5 \mathrm{ml}$ screw-cap glass vials. Each vial was incubated at $10,15,20,25,30$ and $37^{\circ} \mathrm{C}$, respectively. Samples of $0.1 \mathrm{~m} l$ were taken at 0 and $1 \mathrm{~h}$, and immediately titrated.

\section{Results}

\section{Viral Adsorption on Cells}

The percentages of virus adsorbed on the six cell lines at the temperatures tested are shown in Fig. 1. We did not observe a clear relationship between temperature and the adsorption capability of the viruses. As shown in the figure, in CHSE-214 cells at $20^{\circ} \mathrm{C}$ all the viruses adsorbed in percentages higher than $80 \%$, and in FHM cells at $25^{\circ} \mathrm{C}$. On EPC and BB cells we did not find a temperature at which all the viruses exhibited a high adsorption ability (we subjectively considered percentages of adsorption higher than $75 \%$ as high adsorption ability). Even HBR showed low percentages of adsorption at all the temperatures assayed in these two cell lines, and in BB it was unable to adsorb at 20,25 or $30^{\circ} \mathrm{C}$. 

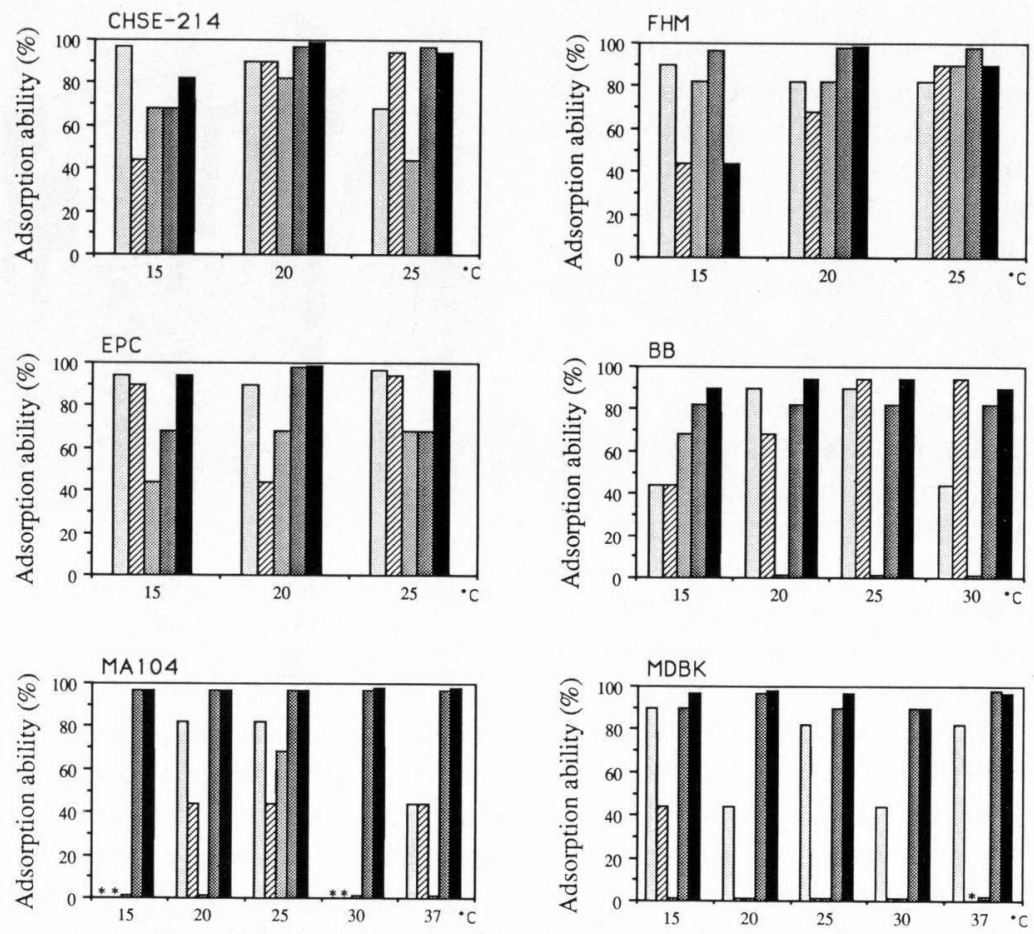

Fig. 1. Adsorption of the five fish rotaviruses on cell lines.

Data are shown as percentage of virus adsorbed on the cells.

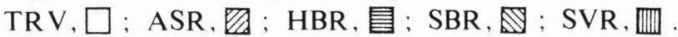

*: Not Tested.

The mammalian cell lines showed the highest variability. SBR and SRV showed high percentages of adsorption to both cell types (mammalian and poikilothermic). In contrast, ASR and HBR showed low adsorption capability on these cells.

To determine the optimum temperature for the incubation of the five viruses during the adsorption period, we analyzed the percentage of adsorption of these viruses on each cell line and at each temperature, by means of the mean $(\mu)$ and the standard deviation $(s)$. In this sense, a high $\mu$ of adsorption percentages with a low $s$ indicates that the five viruses present a high adsorption ability on the corresponding cell line and incubation temperature. On the other hand, the higher $s$ value indicates the higher differences in adsorption ability between the five viruses. As shown in Table 1, high average of percentages of adsorption with low $s$ were obtained in two cases, viz. on CHSE-214
Table 1. Effect of temperature on the adsorption of the five fish rotaviruses.

\begin{tabular}{lllllll}
\hline \multirow{2}{*}{ Cell line } & & \multicolumn{5}{c}{ Temperature $\left({ }^{\circ} \mathrm{C}\right)$} \\
\cline { 3 - 7 } & & \multicolumn{1}{c}{15} & \multicolumn{1}{c}{20} & \multicolumn{1}{c}{25} & 30 & 37 \\
\hline CHSE-214 & $\mu$ & 71.8 & 91.6 & 79.4 & & \\
& $s$ & 17.55 & 6.02 & 20.59 & & \\
FHM & $\mu$ & 71.4 & 85.8 & 90.0 & & \\
& $s$ & 22.87 & 11.55 & 5.06 & & \\
EPC & $\mu$ & 78.0 & 79.8 & 84.8 & & \\
& $s$ & 19.56 & 21.09 & 13.76 & & \\
BB & $\mu$ & 65.6 & 66.8 & 72.0 & 62.0 & \\
& $s$ & 18.99 & 34.56 & 36.27 & 35.71 & \\
MA104 & $\mu$ & 64.7 & 64.0 & 77.6 & 65.0 & 56.6 \\
& $s$ & 45.73 & 37.41 & 19.97 & 45.96 & 37.06 \\
MDBK & $\mu$ & 64.2 & 47.8 & 53.8 & 44.8 & 69.3 \\
& $s$ & 37.25 & 43.65 & 44.18 & 40.25 & 40.18 \\
& & & & & &
\end{tabular}

$\mu$ : mean of the adsorption of the viruses on each cell line.

$s$ : standard deviation of the mean. 
cell line at $20^{\circ} \mathrm{C}$ and on $\mathrm{FHM}$ cell line at $25^{\circ} \mathrm{C}$. This result indicates that in these two lines the use of the same incubation temperature could be possible for an effective adsorption of the five viruses. In the rest of the cell lines the minimum $s$ value was 13.75 , which means that in these cell lines the temperature affects the adsorption ability of the five fish rotaviruses differently.

\section{Cell Susceptibility and Virus Replication}

Only three cell lines (CHSE-214, EPC and $\mathrm{BB})$ were able to support the replication of the viruses, $\mathrm{EPC}$ and $\mathrm{BB}$ at $15^{\circ} \mathrm{C}$, and CHSE-214 at 15 and $20^{\circ} \mathrm{C}$ (Table 2). The five rotaviruses grew fastest (in less than 1 week) in CHSE-214 line, causing destruction of the monolayer in one to two weeks. BB was the optimum for SBR and SRV which produced CPE in 4 days and monolayer destruction in 1-2 weeks, but this line was not susceptible for ASR. The replication of all the viruses was very slow in EPC cell line and, in the case of TRV and SRV no destruction of the monolayer was detected.

The results were quite similar when testing the titers of virus produced in these cells since there is a certain relationship between the time to appearance of CPE and the viral titer ob-

Table 2. Cell susceptibility to the five fish rotaviruses.

\begin{tabular}{lcccccc}
\hline \hline Cell line $\begin{array}{c}\text { Tem- } \\
\text { perature } \\
\left({ }^{\circ} \mathrm{C}\right)\end{array}$ & \multicolumn{5}{c}{ Rotaviruses } \\
\cline { 3 - 7 } CHSE-214 & 15 & $5 / 16^{*}$ & $3 / 14$ & $3 / 12$ & $2 / 6$ & $3 / 13$ \\
& 20 & $4 / 20$ & $3 / 15$ & $2 / 7$ & $3 / 13$ & $3 / 15$ \\
& 25 & NC & NC & NC & NC & NC \\
EPC & 15 & $30 /-$ & $29 / 33$ & $30 / 40$ & $30 / 38$ & $35 /-$ \\
& 20 & NC & NC & NC & NC & NC \\
& 25 & NC & NC & NC & NC & NC \\
& 30 & NC & NC & NC & NC & NC \\
BB & 15 & $30 /-$ & NC & $20 /-$ & $4 / 16$ & $4 / 5$ \\
& 20 & NC & NC & NC & NC & NC \\
& 25 & NC & NC & NC & NC & NC \\
& 30 & NC & NC & NC & NC & NC
\end{tabular}

(Data are shown in days post infection).

*: Days to appearance of CPE/Days to total destruction.

-: No total destruction detected after 45 days.

NC: No CPE detected after 45 days.

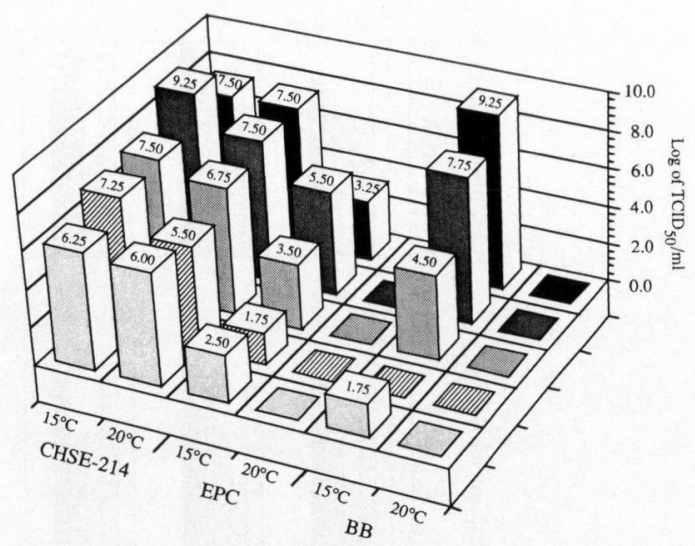

Fig. 2. Replication of fish rotaviruses on cell lines. TRV, $\square$; ASR, $\mathbb{Q}$; HBR, 目; SBR, $\mathbb{Q}$; SR V, 洏

tained (the faster development of CPE and total lysis corresponded to the higher viral titer obtained). As shown in Fig. 2, CHSE-214 cells again proved to be the optimum for rotavirus production, except for SRV, which showed the highest titer in BB cells at $15^{\circ} \mathrm{C}\left(10^{9.25} \mathrm{TCID}_{50} /\right.$ $\mathrm{ml}$ ). In general, the titers produced in CHSE214 at $15^{\circ} \mathrm{C}$ were greater than at $20^{\circ} \mathrm{C}$, with the maximum virus titer obtained being $10^{9.25}$ $\mathrm{TCID}_{50} / \mathrm{ml}$ for SBR.

EPC cells showed the lowest susceptibility to the five fish rotaviruses, displaying a maximum titer of $10^{5.5} \mathrm{TCID}_{50} / \mathrm{m} l$ for SBR. BB exhibited a variable behaviour. Whereas SRV and SBR grew to high titers in BB, this line had low susceptibility to HBR $\left(10^{4.5} \mathrm{TCID}_{50} / \mathrm{ml}\right)$ and TRV $\left(10^{1.75}\right.$ TCID $\left._{50} / \mathrm{ml}\right)$, and the ASR failed to grow in this cell line.

\section{Thermal Inactivation}

The possible loss of infectivity during the $1 \mathrm{~h}$ adsorption period at different temperatures was followed. No significant decrease in infectivity of the five rotaviruses was seen at any temperature, the losses being never higher than $0.33 \mathrm{log}$, which rules out possible thermal inactivation of the rotaviruses during the adsorption period.

\section{Relation between Adsorption and Viral Replication}

In those cases when the cells exhibited susceptibility to the fish rotaviruses, we compared 

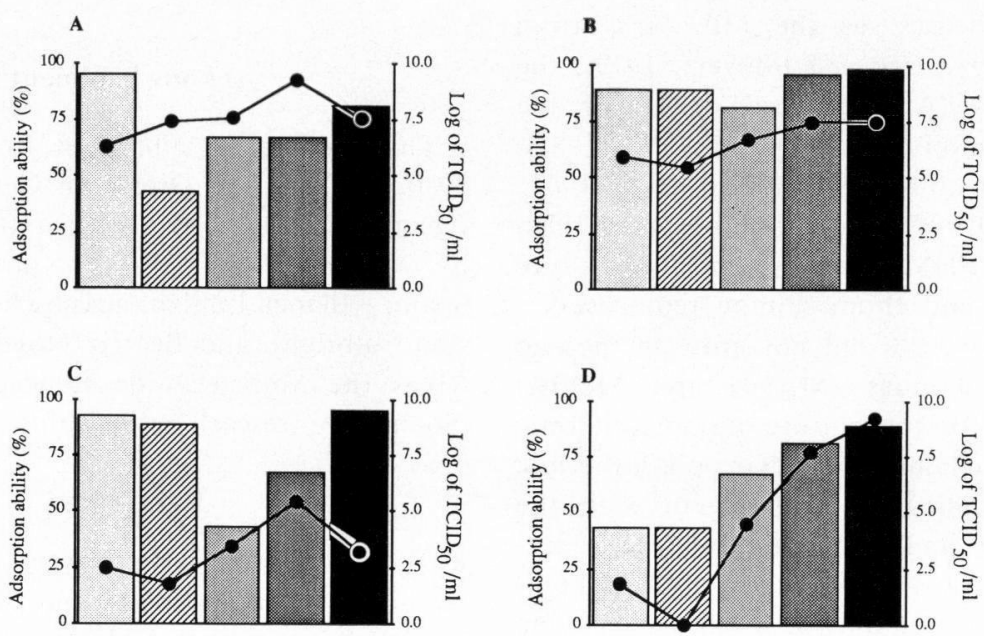

Fig. 3. Relationship between adsorption and replication of fish rotaviruses on cell lines.

Histograms show the percentages of adsorption of the viruses on the cell lines; the scale is shown at left vertical axis. (TRV, $\square$; ASR, 冒; HBR, $\mathbb{N} ;$ SBR, 圆; SR V, 鮞).

The linegrams show the viral production in $\mathrm{Log}$ of the $\mathrm{TCID}_{59} / \mathrm{ml}$; the scale is shown at right vertical axis. $\mathrm{A}$, on $\mathrm{CHSE}$ at $15^{\circ} \mathrm{C}$; $\mathrm{B}$, on $\mathrm{CHSE}$ at $20^{\circ} \mathrm{C}$; $\mathrm{C}$, on $\mathrm{EPC}$ at $15^{\circ} \mathrm{C}$; $\mathrm{D}$, on $\mathrm{BB}$ at $15^{\circ} \mathrm{C}$.

Correlation coefficients: $\mathrm{A}, \mathrm{CC}=-0.38$ (no significant, $\mathrm{NS}$ ); $\mathrm{B}, \mathrm{CC}=0.572(\mathrm{NS})$; $C, C C=-0.476(\mathrm{NS}) ; \mathrm{D}, \mathrm{CC}=0.984$ (Significant, $p<0.01$ ).

the percentages of viral adsorption and the viral titers of the five viruses, to know if there was some relationship between adsorption and replication. We employed a correlation test, with the null hypothesis being $H_{0}: \rho=0$ (this implies that both variables are uncorrelated) (Sokal and Rohlf, 1981). If the correlation coefficient (CC) is significant, both variables analyzed are correlated.

As shown in Fig. 3, only in BB cells we can reject $H_{0} \quad(\mathrm{CC}=0.984, p<0.01)$, which means that a correlation exists between adsorption and replication, and then, those viruses with higher adsorption ability will show higher replication titers in this cell line at $15^{\circ} \mathrm{C}$. In the other cases, no correlation exists between both parameters.

\section{Discussion}

In spite of the development of highly sensitive methods for the rapid detection of fish viruses such as immuno-dot or ELISA techniques, cell cultures are still necessary for the isolation, production and characterization of a virus. For this reason, it is important to determine the optimal conditions for growing virus, including the cell line to be employed and the optimum temperature of incubation for its replication. We agree with Fendrick et al. (1982), that it is important to take into account not only the rapidity of $\mathrm{CPE}$ appearance but also the final viral titer obtained.

In the present study, only three cells (CHSE214, EPC and BB) of the six cell lines tested supported the replication of the five fish rotaviruses (Fig. 2). As observed, SRV produced the highest titer in $\mathrm{BB}$, while the other 4 viruses replicated better in CHSE-214. Regardless of the cell lines, the optimum temperature for replication of these viruses was $15^{\circ} \mathrm{C}$, and they replicated at $20^{\circ} \mathrm{C}$ only in the $\mathrm{CHSE}-214$ cells

As related above, the five rotaviruses failed to produce CPE in FHM cells. This result agreed with those reported previously by the authors for the TRV (Lupiani et al., 1989). Some other researchers have published similar behaviour of this cell line for other reo- or 
rota-like fish viruses, as the $13 \mathrm{P}_{2}$ virus from oyster, Crassostrea virginica (Meyers, 1979), the catfish reovirus (Amend et al., 1984) or the landlocked salmon virus (Hsu et al., 1989). However, other authors (Ahne and Kölbl, 1987; Plumb et al., 1979; Schwedler and Plumb, 1982) found that the FHM cells were useful to culture golden shinner and chum salmon reoviruses.

Our fish rotaviruses did not grow in the two mammalian cell lines (MA104 and MDBK) generally used for the culture of homeothermic rotaviruses, which supports their poikilothermic origin. This finding is in agreement with the distinct protein and RNA electrophoretic patterns exhibited by the fish rotaviruses in comparison with those shown by SA11 (bovine rotavirus) and Reo type I (human reovirus) viruses (Samal et al., 1989; Samal et al., 1991).

Interestingly, when the adsorption assays were conducted, most of the viruses were able to adsorb on all the cell lines, at least at some temperatures. However, the HBR virus exhibited a narrow spectrum of adsorption because the virus adsorbed on BB and MA104 cells only at one temperature, and it failed to adsorb on MDBK at any temperature tested.

A clear relationship was not found between the adsorption ability and the temperature of incubation during the viral adsorption. So, the increase of temperature do not always affects increasing or decreasing the adsorption of the virus. We could assume that the viruses were inactivated during the adsorption period mainly by the highest temperature. In this way, the titer of virus adsorbed (measured as the difference between the total virus inoculated and the titer of virus recovered after that period) would be higher than the real value. However, this posibility was ruled out because in the thermostability assay the rotaviruses proved to be very stable at all the temperatures tested.

The aim of this study was to determine which cell line and which temperature of incubation was the optimal for the replication of these viruses. From the results obtained we conclude that CHSE-214 can be considered as the optimal cell line for the culture of the rotaviruses because they produce relatively high titers when the infected cells are incubated at $15^{\circ} \mathrm{C}$.

\section{Acknowledgments}

This work was supported by Grants MAR 89-0270 from the Dirección General de Investigación Cient fica y Técnica (DGICYT), and by XUGA70708888 from Xunta de Galicia, Spain. Blanca Lupiani acknowledges the Comisión Fulbright, and Beatriz Novoa and Carmen Rivas the Ministerio de Educación y Ciencia (Spain), for researh fellowships.

\section{References}

Ahne, W. and O. Kölbl (1987): Occurrence of reovirus in European cyprinid fishes (Tinca tinca Lin.; Leuciscus cephalus Lin.). J. Appl. Ichthyol., 3, 139-141.

Amend, D. F., T. McDowell and R. D. Hedrick (1984): Characteristics of a previously unidentified virus from channel catfish (Ictalurus punctatus). Can. J. Fish. Aquat. Sci., 41, 807-811.

Baya, A., A. E. Toranzo, S. Núńez, J. L. Barja and F. M. Hetrick (1990): Association of a Moraxella sp. and a reo-like virus with mortalities of striped bass, Morone saxatilis. In "Pathology in marine science" (ed. by F. O. Perkins and T. C. Cheng). Academic Press, New York; pp. 91-99.

Dopazo, C. P., S. K. Samal, T. H. McPhillips, J. L. Barja and F. M. Hetrick (1989): Biochemical comparison of five fish rotaviruses. 13th American Fish Health Conference. Annapolis, Maryland, USA, p. 86.

Fendrick, J. L., W. J. Groberg, Jr. and J. C. Leong (1982): Comparative sensitivity of five fish cell lines to wild type infectious hematopoietic necrosis virus from Oregon sources. J. Fish Dis., 5, 87-95.

Hetrick, F. M., S. K. Samal, S. Marshall and T. H. McPhillips (1989): Reovirus of aquatic animals. In "Recent advances in microbial ecology" (ed. by T. Hattori, Y. Ishida, Y. Maruya, R. Y. Morita and A. Uchida). Japan. Sci. Soc. Press, pp. 582-587.

Hsu, Y.-L., B.-S. Chen and J.-L. Wu (1989): Characteristics of a new reo-like virus isolated from landlocked salmon (Oncorhynchus masou Brevoort). Fish Pathol., 24, 37-45.

Lupiani, B., C. P. Dopazo, A. Ledo, B. Fouz, J. L. Barja, F. M. Hetrick and A. E. Toranzo (1989): New syndrome of mixed bacterial and viral etiology in cultured turbot Scophthalmus maximus. J. Aquat. Anim. Health, 1, 197-204.

Meyers, T. R. (1979): A reo-like virus isolated from 
juvenile American oyster (Crassostrea virginica). J. Gen. Virol., 43, 203-212.

Marshall, S. H., S. K. Samal, T. H. McPhillips, A. R. Moore and F. M. Hetrick (1990): Isolation of a rotavirus from smelt, Osmerus mordax (Mitchell). J. Fish Dis., 13, 87-91.

Moore, A. R., M. F. Li and M. McMenemy (1988): Isolation of a picorna-like virus from smelt, Osmerus mordax (Mitchell). J. Fish Dis., 11, 179-184.

Plumb, J. A., P. R. Bowser, J. M. Grizzle and A. J. Mitchell (1979): Fish viruses: A double-stranded RNA icosahedral virus from a North American cyprinid. J. Fish. Res. Board Can., 36, 1390-1394.

Reed, L. J. and H. Müench (1938): A simple method of estimating fifty percent endpoints. Am. J. Hyg., 27, 493-497.

Samal, S. K., C. P. Dopazo, T. H. McPhillips, A. E. Toranzo and F. M. Hetrick (1989): Molecular characterization of five fish rotaviruses. Proceed- ings of the IV EAFP International Conference. Santiago de Compostela, Spain, p. 98.

Samal, S. K., C. P. Dopazo, K. Subramanian, B. Lupiani, S. B. Mohanty and E. M. Hetrick (1991): Heterogeneity in the genome RNAs and polypeptides of five members of a novel group of rota-like viruses isolated from aquatic animals. J. Gen. Virol., 72, 181-184.

Schwedler, T. E. and J. Plumb (1982): In vitro growth kinetics and thermostability of the golden shiner virus. J. Wildl. Dis., 18, 441-446.

Sokal, R. R. and F. J. Rohlf (1981): Biometry. W. H. Freeman and Company, New York, 859 pp. Winton, J. R., C. N. Lannan, J. L. Fryer, R. P. Hedrick, T. R. Meyers, J. A. Plumb and T. Yamamoto (1987): Morphological and biochemical properties of four members of a novel group of reovirus isolated from aquatic animals. $J$. Gen. Virol., 68, 353-364. 